and re-inoculations put the matter beyond doubt. Though the fungus can attack the leaves, really serious damage occurs only when the fungus invades the root and penetrates to the stem. The whole plant then wilts, the leaves turn yellow and drop rapidly. The disease is carried through soil and water, for no evidence of acrial dissemination was found; leaf lesions appear to be initiated only by water-splashes from the soil. The monograph gives all necessary information on literature, symptoms, colonization of the host, the pathogen, epidemiology, climatic factors, alternative hosts, distribution and control. Practical measures against foot-rot are mainly items of hygiene designed to prevent spread of the organism to a holding and from plant to plant. Pepper plants are grown on mounds and most of the plantations were clean weeded. Perhaps, rather surprisingly, one of the main items of control is to allow grass cover to grow between the plants. In an area where rainfall can be 4 in. in a day, this prevents the washing of soil away from infected mounds to infect neighbouring healthy plants. This is an index of the thoroughness of the investigation, for only very painstaking work could lead to such a simple but effective measure. Whereas about 50 per cent pepper holdings were destroyed during the 1953-56 epidemic, the prevalence is now about 5 per cent. It could probably be reduced further if the conservatism of the growers could be overcome and full hygiene applied. The work is also welcome as a piece of collaboration, for Paul Holliday was a member of the pool of plant pathologists maintained by the Cornmonwealth Mycological Institute and W. P. Mowat worked under the ægis of the Colonial Office, while a further application lies in the hands of the young Department of Agriculture for Sarawak.

\section{Russian Texts of Western Petrology}

Two main advantages of an organized science, as is now in the process of creation in the U.S.S.R., are: (1) the provision of extensive and comprehensive abstracting journals; (2) Russian translations of all really important works published outside the U.S.S.R. Taking as an example works on petrology published in the English languago, excellont Russian translations are available of the works by Tyrrell (1927); Bowen (1934), Harker (1937), Fairbairn (1949), Barth (1956), Williams, Turner and Gilbert (1957) and Turner and Verhoogen (1961). The last-mentioned book, dealing with the petrology and petrogenesis of igneous and metamorphic rocks, was published in a Russian translation and edited by V. P. Petrov, by Publication of Foreign Literature in Moscow, at the price of $3 r .85 k$. Much attention in the U.S.S.R. is directed to the petrology and petrogenesis of sedimentary rocks, which the Russian specialists in this field call 'lithology' and 'lithogenesis' respectively. The principal Russian translations of publications in this line of investigation include: Brindley et al., X-ray Identification and Crystal Structure of Clay Minerals (1951), and Grim, Clay Minerals (1956). Lately, two important volumes have been published, namely, Problems of Mineralogy of Clays, edited by V. P. Petrov, which contains nineteen articles by various British and American authors, published during 1958-60 (Pp. 463. Moscow: Publication of Foreign Literature, $1962.1 r, 83 k$.) and Geochemistry of Lithogenesis, edited by A. B. Ronov (Pp. 459. Moscow: Publication of Foreign Literature, 1963. 2r. 21k.), which contains Russian translations of ten recent articles by British and American authors dealing with hydrogen ion concentration; redox index; chemical weathering; behaviour of silica in water and in sediments during the process of diagenesis; separation of iron and manganese during sedimentation; factors influencing the concentration of rare metals in sea-water; petrochemical provinces and petrochemical tendencies; geochemistry of the sea; and, finally, the recently revised geochronological scale by Prof. A. Holmes (1960). A.ll these translations naturally help to bridge the linguistic barriers in the field of petrology, but, strange to tell, they also prove to be useful in an unexpected way, namely, in providing Russian texts for those English-speaking petrologists who are trying to learn 'scientific' Russian.

\section{Solid-state Physics}

No. 37 (Series II) of the French Bibliographical Digest, entitled Solid State Physics, deals with investigations carried out in France prior to 1961 and mainly during the years 1955-60 inclusive (Pp. 182. New York, N.Y.: The Cultural Center of the French Embassy, 1963). The bibliography was compiled by Prof. J. Friedel, and in his brief introduction he refers to the period since 1956 as the 'third cycle' in the history of solid-state physics in France. The first cycle was the period between the First and Second World Wars, when the fundamental work on wave propagation in crystals by Brillouin and the classical experimental work on magnetism by Weiss, Néel, Foex and others was carried out $\mathrm{X}$-ray investigations by Laval, Guinier and Cauchois, and work on Raman spectra and on luminescence by M. Curie and Destriau, were also made at this time. The post-war period was marked by Néel's investigation of antiferro- and ferrimagnetism, Laval's investigation of phonon scattering of $\mathrm{X}$-rays, Crussard and Lacombe's metallurgical work and Castaing's development of X-ray microbeam analysis. This was followed, in 1950, by the commencement of industrial activity in the semiconductor and nuclear energy fields. The contents of the Digest consist of a list of French laboratories connected with solid-state physics in 1960; books, including lectures or papers at summer schools, congresses or colloquia published before or during 1960; and the main bibliography, divided into sections according to subject-matter, of 964 research papers published between 1955 and 1960. The English translation of the French title is given together with, in most cases, a short abstract of the contents of the paper.

Soil and Plant Nutrition Aspects of the Sulphur Cycle

THere has probably been more concern in industrial areas over damage to crops from excess sulphur in the atmosphere than over possible deficiency in the soil. But sulphur deficiency has been established in many regions and considerable research has been carried out on factors affecting the supply of sulphur to the plant. The present position is reviewed by $D$. C. Whitehead in a recent issue of Soils and Fertilizers (27, No. 1. Commonwealth Bureau of Soils, Rothamsted, 1964). The sulphur content of plant tissues amounts to an absorption of 10-40 lb. per acre; the loss of sulphur in drainage water is of the order $30 \mathrm{lb}$. per acre per annum. The total sulphur in normal soils ranges from about 20 to 2,000 p.p.m. and has come originally from sulphides in the parent rock, but a large fraction is now associated with the organic matter so that there is frequently a correlation of sulphur, carbon and nitrogen. Several groups of bacteria can oxidize sulphur and its compounds, but little is known of the chemical nature of the sulphur-organic compounds and of their transformations. There is some retention of sulphate by sesquioxides and kaolinitic clays in lower layers of the soil profile; there is also anion absorption under acid conditions and possibly antagonism between sulphate and phosphate. Sources of sulphur for the plant, apart from the soil, are atmospherie hydrogen sulphide and sulphur dioxide, and sulphate from sea spray: Changes in the composition of fertilizers and fungieides have redued the amount of sulphur being added to soils and hence deliberate additions-and gypsum app -ars to be the obvious choico - may become necessary in many situations.

\section{Permanent Scottish Field Centre}

The Scottish Field Studies Association has announcod the opening of a permanent Centre at Kindrogan, Perthshire. A permanont residont warden, Bruce Ing will be in residence during 1964 , and it is expected that the Centre 